\title{
SIDHU'S PREDICAMENT
}

\author{
Dr. GURURAJ KIDIYOOR
}

"I think we can no longer postpone this decision," said Sidhu to his wife Uma. "Look at all these attractive offers on two wheelers" He was reading out of the day's newspaper. "Good discounts, no down payment and very easy EMl's."

\section{BACKGROUND}

It was quite some time since Sidhu and his wife were considering buying a new vehicle. They lived, with their four-year old son Ramu, in Sidhu's ancestral house, $10 \mathrm{~km}$ away from his place of work. Sidhu worked in a private company and Uma was a home-maker. Sidhu earned around ' 4.50 lakhs gross per year. This included his salary plus a rental income of ' 80000 from a property Sidhu owned (currently occupied by a bank.)

Immediately after his wedding in 2002, Sidhu had purchased a geared motorbike which cost him ' 50000 on road. He had made a cash purchase of the bike at that time. He had used this bike extensively till 2008. In August 2008 Sidhu purchased a car that cost him close to ' 3.00 lakhs on road. He borrowed from a bank near his office on a 5 year EMI plan that came to ' 5575 per month. After he came to own a car he hardly used his bike. The condition of the bike deteriorated a bit due to poor maintenance and infrequent usage.

${ }^{1}$ Case Prepared by Gururaj Kidiyoor, Professor $\odot$ T A Pai Management Institute, Manipal-576104, () 2012. The case is written for the purpose of class room discussion and does not demonstrate a correct or incorrect handling of an administrative situation.

${ }^{2}$ Equated Monthly Installments

\section{NEW VEHICLE - NEED}

Ramu was admitted to a play school, $3 \mathrm{~km}$ from home, in June 2009. His school operated between 9.00 a.m. to 12.20 p.m. This obliged Sidhu to use his bike regularly. Every day he would drop Ramu at his school en route to his office. At 12.20 p.m Uma would pick Ramu from school in the car (she held a valid driver's license). So Sidhu now began to use his bike daily. However, this arrangement was quite uncomfortable for him as he began getting back pain from kick-starting the bike. Sidhu also found that the cache provided in the bike was inadequate to carry his Tiffin box and rain gear (during monsoon).

The next year Ramu was to be admitted to the same school in LKG. The school had a bus facility and the pick-up and drop charge was a subsidized Rs. 150 per month. However both Sidhu and Uma were not comfortable sending such a small boy all alone in the school bus and the current system was causing physical discomfort to Sidhu. During summer vacation they started exploring alternatives that would make their daily trips convenient and flexible and in this regard as Uma knew cycling, purchase of a new, gearless two wheeler was considered. This would enable both of them to use both of the vehicles (The car and the new two-wheeler). Moreover, as Uma did most of the shopping for the family, she thought the new two-wheeler can come in handy for this task as well.

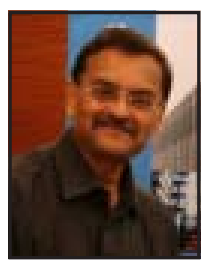

Dr. Gururaj Kidiyoor

Professor,

T A Pai Management Institute

Manipal - 576014

Email : gururaj@tapmi.edu.in

Teaching Notes : Available on request 
Much before Sidhu's interest was aroused by the newspaper advertisement, the couple had more or less decided on a 4 strokes, $100 \mathrm{cc}$, and gearless scooterette by the name Funda Activa. They had seen advertisements on TV and large advertising billboards for two wheelers which raised their awareness of all the popular brands. As Sidhu's graduation had been in Mechanical Engineering, he knew that a 4 stroke engine had certain advantages over a 2 stroke engine. Hence gearless bikes with 2 stroke engines were out of consideration. Among the four stroke gearless bikes, smaller models (Less than $95 \mathrm{cc}$ ) were not favoured. As Sidhu was tall and heavily built, he felt these models would not provide enough leg room for him and also they would not generate enough power to carry all three family members if a situation required. Finally they zeroed down on two 4 stroke models Funda Activa and a competing brand called "Novastia". Sidhu and his wife were quite impressed with the looks and styling of the latter. However there were other things in favor of Funda Activa. Sidhu's elder brother had purchased a Funda Activa a year ago and he was very happy about it's fuel efficiency ${ }^{3}$ which he had claimed was about $50 \mathrm{~km}$ per liter of petrol. Moreover a colleague of Sidhu, also a Funda Activa user, was all praise for the bike. Sidhu himself had read very positive reports on this vehicle in the popular auto magazine called "Auto India". As for "Novastiva," Sidhu was told by a friend that the vehicle had a problem with electronic start. Since electronic start was very important to the couple, they decided on Funda Activa. It cost 499000 on-road and had a standard delivery period of two months as there was a good demand for this vehicle. On May $17^{\text {th }}$ 2010 Sidhu booked this vehicle at the local dealer by paying 3000 in cash. The vehicle was to be delivered in July 2010.

\section{THE BANK}

The Sidhu family had individual accounts in a nationalized bank branch near their residence. Sidhu and Uma had savings bank account and Ramu had a minor's account. The combined amount in these

${ }^{3}$ In 2010, petrol cost was about Rs.50 per liter. accounts in May 2010 was about '95000. Uma also had a locker in this bank where she kept her jewelry. Additionally, about '180000/- was kept as fixed deposit in Uma's name in the same bank.

Around this time, during one of his routine visits to this bank, Sidhu was approached by the bank manager, Mr.Janardhan, who said the bank would be more than happy to give Sidhu any loan - housing, personal or vehicle. Though Sidhu was not thinking of taking any loan, this prompted him to think about the payment that he would have to make on delivery of his new scooterette and enquired the terms for a loan of ' 40000 with four year repayment period. $\mathrm{He}$ was told that the EMI for this loan would be " 1200 per month.

Sidhu spoke about this to his wife who was a bit surprised as she thought they would be paying from their savings for the new vehicle. Sidhu told her that it would be better to go in for the loan as the low EMI would not pinch them. "It is better than being short of "46000 overnight" he said. Moreover, as the occupants of his inherited property had indicated their wish to vacate the premises by June 2010. Sidhu thought there was now a need to plan his finances a bit till he got a new tenant. The next day, which was on $20^{\text {th }}$ May, he went to the bank and took the loan application papers 4 . Janardhan was quite happy that he had a roped in a new customer for loans. The bank being located in a residential area, had more deposits than advances. Every year Janardhan would fall short of his target on advances. However Sidhu did not do anything on the loan application form immediately. He just kept the paper with him. He was still not very sure about availing the loan.

\section{THE VEHICLE DEALER}

On $29^{\text {th }}$ May Sidhu received a letter from the dealer confirming his booking of the vehicle. Sidhu noticed an error in the letter; He had booked a silver colored bike but was now being allotted a black colored bike. He immediately called the dealer on phone and told him about this mistake. The dealer apologized and

\footnotetext{
${ }^{4}$ The steps for vehicle loan processing is given in
} Annexure - 1 
said it would be corrected immediately. Sidhu then asked the dealer how many more days he would have to wait for the delivery of the bike. The dealer assured Sidhu, there will not be any further delay on account of the mistake and the delivery will be still two months from the date of booking.

The dealer then asked Sidhu whether he was in a hurry for the delivery of the bike and when Sidhu asked him why he was being asked this, he was informed that one unit was available for immediate delivery and Sidhu could have it if he wished. By some mistake, the factory had shipped one unit extra to this dealer and he was in a position to sell it off. But there was one snag. Sidhu had booked a silver colored model whereas the available unit was gold colored. On hearing this Sidhu's preference for color vanished. As Ramu's school was to open on $2^{\text {nd }}$ June, he agreed to take the vehicle after consulting briefly with Uma. The dealer then asked Sidhu to come over immediately with full payment so that the vehicle could be delivered on $31^{\text {st }}$ May ( $30^{\text {th }}$ was a Sunday) at 4.00 p.m. The vehicle would be kept ready with PDI (Pre Delivery Inspection) and temporary registration. The payment part reminded Sidhu of the proposal by the bank manager, Janardhan, and he informed the dealer that the vehicle would be hypothecated to the bank as he was availing a loan for this purpose. The dealer also asked Sidhu to hurry as there was a long wait list for the product and there were other customers who were putting pressure on him for delivery.

\section{RUSH FOR THE LOAN}

Sidhu then went to the bank immediately with his loan application form duly filled and with some other necessary documents. He met Janardhan and told him about the urgency. Janardhan expressed his inability to process the loan on the same day as it was too short a notice. Sidhu was disappointed. However Janardhan told Sidhu to make the payment now from his available balance in the bank account. "Your loan application will be processed first thing on Monday and we will deposit 40000 in your account. Sidhu thanked Janardhan, submitted his loan application to the bank and left immediately.
Next, Sidhu went to the dealer and gave a cheque drawn on his personal account (of Janardhan's bank branch) for the required amount. The dealer did not accept the cheque as he wanted a demand draft and nothing less. He also suggested Sidhu to avail loan from GK countrywide whose representative was present right at the dealer's place. The GK countrywide representative told Sidhu that the terms offered by his company were much better than Sidhu's bank and the process also was much simpler. Sidhu however declined this offer.

Sidhu rushed back to his bank to get a demand draft but it was already 1.45 p.m on a Saturday and Janardhan said it was too late to issue a demand draft. He assured Sidhu that on Monday the draft would be issued first thing in the morning. Sidhu then telephonically requested the dealer to give him more time for payment. The dealer obliged and said he would wait till 10.30 a.m. on Monday, beyond which if payment was not made, the offer would go to some other willing customer.

\section{THE D DAY}

Sidhu was the first customer at the bank on $31^{\text {st }}$ May and he was in for a major disappointment. Due to heavy rains and thunderstorms on Sunday, the bank's computers had got delinked from the satellite. "I am sorry Mr.Sidhu, we can not issue a demand draft now as our draft issuing process is computerized" said Janardhan. "Computer serviceman will be here any moment and we will sort out the problem soon. If you can wait for an hour or so I think we will be in a position to issue your draft". Sidhu asked if it was possible for him to draw cash and when the answer was in affirmative, he drew 46000 cash from his account. When Sidhu was about to leave, Janardhan apologized (Sidhu could see that Janardhan was terribly embarrassed) for the inconvenience caused, but promised him that the loan application would be processed immediately. "I have gone through your papers. They are in order. You only need to bring two 
50 stamp papers ${ }^{5}$ so that we can prepare the loan agreement". Sidhu said he would get them and left the bank. He headed straight to the dealer to make payment for his new vehicle. It was 10.00 a.m., Monday $31^{\text {st }}$ May 2010.

An hour later, Sidhu came home and told his wife Uma "Yes, everything is done. I have paid the money to the dealer. We need to go there at $4.00 \mathrm{p} . \mathrm{m}$ to take delivery of the bike". Uma was happy. "I have seen the panchangam ${ }^{6}$ and it's a good day to buy something new" she said.

"By the way I paid the entire amount in cash. There was some computer problem at the bank so draft could not be taken. But Janardhan helped to draw cash fast. Good chap" continued Sidhu. "However I have decided not to take the loan. The procedure is a pain. Thanks to that man Telgi I I now have to go to the State Bank and stand in a long line to buy two stamp papers. Silly practices they have, these banks. I don't want to waste two hours standing in a line in the peak of hot summer for some stupid stamp paper."

"Suits me fine" said Uma "right from the beginning I was wondering why are you borrowing money for such a small amount"

"It is decided then" said Sidhu walking towards the telephone. "I better call up Janardhan and tell him about our decision. He is a nice fellow after all"
At 11.30 a.m. on the same day, Janardhan received a call from Sidhu who thanked him for all the help. He also instructed that his loan application should not be processed as he had now decided not to borrow money for the vehicle. Janardhan was surprised and disappointed at having lost an opportunity. $\mathrm{He}$ wondered what went wrong.

\section{Annexure - 1}

Typical Steps Involved in Vehicle Loan Processing

1. Open account in the bank branch

2. Take the Loan application form

3. Fill the form

4. Take guarantor's signature

5. Submit loan application with 2 pass port size photographs and Salary slip and copy of filed Income Tax returns.

6. Preparation of loan agreement

5 Government issued papers used to legally authenticate a contract/deal between two parties. The stamp papers come in different denominations and are to be purchased by the transacting parties. Stamp papers were sold by Government recognized vendors but in the early 2000's the Government of India abolished this system due to influx of fake stamp papers. From thereon, stamp papers were available in nationalized banks only.

6 Hindu traditional calendar that lists auspicious days and times.

7 Person accused of masterminding the fake stamp paper racket. 